\title{
Social Condition of Japanense Geisha as reflectd in short story madame butterfly by John Luther Long
}

\author{
Basri $^{\text {a, } 1, *}$ \\ ${ }^{a}$ Litelature English Departement Ahmad Dahlan \\ ${ }^{1}$ basri@com.uad.ac.id*; \\ * corresponding author
}

Article history

Received 01-09-2020

Revised 13-10-2020

Accepted 22-10-2020

Keywords

Geisha

Japanese

Social Condition Western

Culture

\begin{abstract}
In this undergraduate thesis, the writer discusses short story Madam Butterfly written by John Luther Long. This study is aimed: (1) to describe the Geisha social life condition in Japanese society as reflected in Madame Butterfly (2) to describe the social class in Japanese society in 1903s as reflected in Madam Butterfly. In doing this research, the writer uses descriptive qualitative method which refers to description of things, characters, meaning and symbols. There are two types of data in this study.The findings of the research show that Geisha in Japan through Cho Cho San the main character in Madame Butterfly was a reflection of Geisha's life condition in Japanese society. The writer conclude that Social condition of Geisha in Japan in 1930s are an entertainer because they are has been train for accompany all of the guests. Serve the drink, singing, dancing and playing music instrument were the Geisha's job while accompany the guest. The guest also did some flirting to the Geisha. In 1930s American missionary and American Navy enter Japan for some mission, there are also American people who married Japanese girl. Beside the Geisha social life condition, there are two class in Japanese society that exist in 1903s Kazoku (Nobleman) and Heinin (Proletar). The social class in Japan in that time is very contrast between the Nobleman and Ploretar. Madam Butterfly include to high class people because of she married to a foreigner because according to Japanese, if they married a foreigner it can rise their social status.
\end{abstract}

This is an open access article under the CC-BY-SA license.

\section{Introduction}

Madam Butterfly is a short story written by John Luther Long, a writer from America which write about a Japanese woman who married a man from Europe. According to University of Virginia, Long based the story on the recollections of his sister, Mrs. Correl, who had been to Japan with her husband, a missionary. In the story Cho Cho San is the main character, she is a Geisha and her nicknamed is Madam Butterfly. This story mainly influenced by a novel Madame Chrysanthemum written by Pierre Loti in 1988. (Pohle, Tawil, Davydovskaya, \& Fleischer, 2011).

Madame Butterfly also interested an American playwright David Belasco and collaborating with Jhon Luther Long adapted it to a one act play : Madame Butterfly: A Tragedy of Japan. Another adapted by David Henry Hwang in 1988 and in 1993 adapted by David Cronenberg into a film. Madame Butterfly not also adapted into play and film but also to an Opera by Giacomo Puccini who compose the orientalist Opera Madame Butterfly at 1904 in Milan. (Robert W. Pohle, 95: 2009)

In the story, madam butterfly fall in love to a missionary Mr. Pinkerton and married. Mr. Pinkerton left her because he have to go back to his country. He promise Madame Butterfly to come 
back to Japan. During Mr Pinkerton left her, she gave birth a boy she named Trouble that she plan to change his name when Mr. Pinkerton back to Japan. When Mr. Pinkerton back to Japan, he already has married an American woman. Mr. Pinkerton wanted to take Madame Butterfly's child. Madame Butterfly is very depression and decide to suicide but she survive (Long, 1898).

A long standing stigma has been placed on Japanese Geisha girls. When someone thinks of a Geisha, they think of a glorified prostitute or call girl. This is far from the truth. Geisha's are entertainers, and they are trained vigorously in art, music and dancing. Become a Geisha is a honor to Japanese girl. According to Japanese, Geisha and prostitutes are different. To make a differences between a Geisha and a prostitues, you can see when they wear a kimono. A Geisha wearing a Kimono with an obi (an sash) tie in the back, but prostitutes tie the obi in the front front. According to the short story of Madame Butterfly Geisha was also called to entertaint American missionary. This is just where the story of a Geisha named Cho Cho San just begun (Wada, 2011).

The writer interested to the story of Madame Butterfly analyze the social condition of Gheisha life in Japan. In this undergraduate thesis, the writer will use literary approach of Mimetic by M.H Abrams and Renne Wellek. Among Jhon Luther Long short story, the writer chooses "Madame Butterfly" to be analyzed through the social condition of Geisha in Japan that reflected in it. The author as the part of society can not be separated from social background and this literary works describe the social condition. There is tragic love story of Geisha in Japan. How geisha struggle to continue her life. Being Geisha for Cho Cho San is not that easy, because she have to face many trouble such as economy and with social. Especially when she gave birth a son without a father beside her son.

Beside it, the writer would like to use sociology analysis based on the society that is reflected by Madame butterfly by Jhon Luther Long in that periode. There is relationship between a literary works and the sociey. Literary work can be viewed as a reflection of life or a picture of society at a certain time.

M.H Abrams also have the conception of the mirror where literary work as imitation of aspect of universe. The universe included part of life such as human being, human society and place of life, like experience of human being, the condition of certain society and others. What is mean by relationship between the work of art and universe is that work of art show many problems that appear in the world. It can be a criticism or a description of life. A literary work describes about the situation of people at a certain time.

The conception of the mirror, then, must be treated with great care in the sociological analysis of lifetime. Above all else, of course, it ignores writer himself, his awareness and intention. Great writers do not set out simply to depict the social world in largely descriptive terms; it might be suggested that the writer by definition has a more critical task, of setting his characters in motion within artificially contrived situations to seek their own private 'destiny', to discover values and meaning in the social world (Eddelbuettel \& Eddelbuettel, 2013).

The writer argue that Madame Buterfly is one of literary work which is reflected about social condition of Geisha in Japan. It can be barometers of the human response to social forces, because leterature delineates man's anxieties, hopes and aspiration. Literature as a reflection of values and of feeling, points both o the degree of change occuring in different societies as well as to the manner in which individuals becomes socialized into the social structure and their response to this experience (Flaubert \& Renoir, 2017).

\section{Theorotocal Framework}

To analyze social condition of the Japanese Society as reflected in Madame Butterfly the writer will use mimetic approach is explanation of arts of painting, poetry, music, dancing, sclupture and the like are all imitation. Imitation is a term, signifying two items some correspondence between them (Groysberg \& Abrahams, 2014).

Mimetic approach can be applied to see a literary work as imitation of aspect of universe. The universe includes past of life such as human being, human society and place of life, like experience of human being, the condition of certain society and others. What is meant by relationship between

Basri (Social Condition of Japanense Geisha as reflectd in short story madame butterfly by John Luther Long) 
the work of art and universe is that work of art show many problems that appear in the world. It can be a criticism or a description of life. A literary work describes about the situations of people at a certain time.

Though mimetic approach of Abram, there is also concept of reflected of society theory of Wallek and Warren where "The artist conveys truth and, necessarily, also historical and social truths. Work of art furnish document bacause they are monument. A harmony between genius and is postulated. Representativeness, social truth, is by definition, both a result and cause of artistic value. Mediocre, average works of arts, though they may seem to modern sociologist better soccial dosuments, are to Taine unexpressive and hence unrepresentative. Literary is not a reflection of the social process, but the essence, the abridgement and summary of history (Wellek, 2017).

Through reading a literay work, a reader can see a social condition where a literary works can be viewed as reflection of a society at a certain time. That is why there is relation between sociology and literature. According to Abrams, there are four approachs that should be noticed to analyze a literary work, one of the four approaches is mimetic approach, it can be applied to see a literary work as imitation of aspect of universe. The universe includes part of life such as human being, the condition of certain society and others. What is meant by relationship between the work of art and universe is that the work of art show many probles that appear in the world. It can be criticism or a description of life. A literary work describes about tha situation of people at a certain time.

The conception of the mirror, then, must be treated with great care in the sociological analysis of literature. Above all else, of course, it ignores the writer himself, his awareness and intention. Great writers do not set out simply to depict the social world in largely descriptive terms; it might be suggested thet the writer by definition has a more critical task, of setting his characters in motion within artificially contrived situations to seek their own private 'destiny', to discover values and meaning in the social world (N. \& A., 2018).

In Abrams, the mimetic approach is the explanation of art as essentially an immitation of aspect of universe. This theory is classical theory which came from Plato and Aristotle. Aristotle says that arts of painting, poetry, music, dancing, sclupture and the like are all imitation. Imitation is a relation term, signifying to items some correspondence between them. Aristotle also points out that literary works are modification of mimetics and creation, imitation and creativity, imagination and reality. Within process of creation, artists are not only to imitate reality, but they also create a world with his creativity power. A world which is created, a new world which is idealized, and can everything is possible to happen even it never happen in real life. Aristotle assumes that literary is a higher something and a s philosophy even literary has higher values than history works.imitation of universe is an imitation of life and human action including human characters, thought or inanimate things and event, the beautiful and moral aspects of the world.

The universe includes part of life such as human being, human society and place of life, like exprience of human being, the condition of certain society and others. What is meant by relationship between the work of art and universe is that the work of art show many problems that appear in the world. It can be a criticism or a description of life. A literary works describe about the situation of people at a certain time.

\section{Method}

In analyzing the novel, the writer uses the research procedure which is not much different from other scientific method. The use of descriptive qualitative method. They are method collecting data, the source of the data, and data analysis technique.

a) The source of Data

The primary data are taken from the main sources: origin short story of Madame Butterfly. the writer reads and the most important data related to the study being analysez. To support the source of data, the writer also needs some secondary data taken from books, journal, critical essay and internet sourcing (website)

b) Method of Collecting Data

W: http://journal2.uad.ac.id/index.php/commicast/index |E: commicast@comm.uad.ac.id 
The method of collecting data is close reading both primary and secondary data. It is done particularly on the social condition about geisha life in Japan that is going to be analysed. The next step is to make a note of important facts in some pieces of papers, related to the problem that will be analysed in this study. The main data are taken from the compehension towards the setting of the novel, narrative, and some dialogues in the novel.

\section{c) Method of Analyzing Data}

The technique that will be used in the data analysis is descriptive qualitative technique.The writer uses the qualitative data because it is appropriate to this research. The technique is started with some quotations and statements described by using some explanation to analyzing and related to the reality of geisha in Japan which is reflected the social condition in Madame Butterfly.

\section{Results and Discussion}

In this chapter, the writer will analyze the text, John Luther Long's novel Madame Butterfly in terms social condition of Geisha in Japan. As the first step of the research, the writer analyzes the roles of Cho Cho San as the main character, she is a Japanese Geisha and her American husband Pinkerton. The major analysis in this chapter focuses on describing the social condition of Geisha in Japan and Class social in Japan in 1930's as seen in Long's Madame Butterfly, which reflect the social condition of Geisha in Japan in 1930's.

A novel show the element of the story with very detail and complete, represent the problem in society completely, the language in the novel also easy to understand that is why a novel is sociological and responsive genre because it very sensitive to the fluctuation of sociohistorical. The most important purpose of literary works is the ability of that literary work in show the another life, different life with daily life.

Social condition is related to behavior of the society that can be tell in a fiction or non fiction. The tradition of society could be seen from the habit, culture, tradition, their believe, religion, the way they think and another. Such as in Madame Butterfly there were back ground of place, character, time where the character experience their life story especially like Cho Cho San or who called Madame Butterfly who were a Geisha. There are differences in sociology and literature but actually can be explain to the meaning of the text (Puspasari \& Suwardi, 2016). It can be understood by the object of the sociology where it study of human such as literature. We can say that literature is an expression of human life that can not be separated from the society. Even sociology and literature is two different things but can be connected and completed each other.

\section{A. Madame Butterfly A Japanese Geisha}

As we know that Geisha is Japanese traditional entertainer, their job were to make a show, dance, singing and accompany the guest, pour them tea, and enkindle the tobacco for their guess. In Madame Butterfly by John Luther Long, Cho Cho San is actually an ex of Geisha. As the Geisha rule, a Geisha do not allow to marry but can have a children by being a mistress. If a Geisha married, they automatically stop being a Geisha but also can be a Geisha again after diforce. Before Cho Cho San marry, she called the Pink Geisha as following quotation :

"When I was out there in 1890 the story of the Pink Geisha, heard it, have you?" (P.1) In my opinion, they called pink Geisha because she was about 15 th years old. One of the condition to be a Geisha is she have in 15 years old age.

Beside the white pale make up and wear the Kimono, how they treat the guess is describe how Geisha doing their job, a the following quotation :

"Her hair had been newly dressed for the occasion and had stuck a poppy in it. Beside, she puts her hand on his arm and smiled wistfully up at him. And when you know what Cho Cho San's smile was like, and her hand and its touh, you will wonder how Pinkerton resisted her. However, he only laughed at her, good naturedly always, and said no." (P.2)

Geisha also good in playing music instrument and singing like what Cho Cho San do, following the quotation: 
"She had acted it all with superb spirit, and now she snatched up her samisen (a traditional Japanese three-stringed lute with a square body, played with a large plectrum), and dramatized this also; and so sure she of life and happiness that this is the song of sorrow and death she sang : " Hikari nodekeki haru no nobe, Niwo sakura no hana skari, Mure kuru hito no tanoshiki ni, Shibashi uki yo ya wasururan." (Sunshine on a quite plain spring, The perfume of the bloomong cherryblossoms, The joy of gathering crowd, Filled with love, forget the care of life)" (P.4)

There are a lot of man who offer Cho Cho San as their wife or mistress but she denied it. Following quotation :

"I will give her a castle to live in said Yamadori breathlessly. The nakodo sight. Cho Cho San refilled his pipe with an incomparable grace. "Ah!" she permitted her lips to breathe very softly. She shall have a thousand servants! Everything her heart wish! cried Yamadori recklessly." (P.9)

\section{B. Social Condition of Geisha in Japan in 1930's}

A geisha strives to stand out with her appearance in order for her to not appear like a prostitute, with her expensive and beautiful kimono, her unique hairstyle and accessories. This is why a prostitute's and a geisha's kimono differs: the kimono worn by a prostitute is cheap and can easily be opened, while a geisha's is very expensive and tricky to put on and take off (Permatasari. 5, 711). The life of a geisha is quite expensive: the make-up, luxurious kimonos, lavish accessories and financially providing for the okiya. The only income as geisha could earn at that time wa payment from entertaining at tea-parties (geisha's entertaining men) or occasionally prostituting, but this small income would not be enough to cover all expense, which is why an income from a danna would make it easier to maintain their luxurious lifestyle. A geisha could have more than one danna if she or her mother wishes in order to bring in more money to the okya house at some occasion, the could have sleepovers at teahouses and occasionally they would have intercourse with the men at the party, even though she was mistress to another man (Gallagher, 2012).

A geisha's way of life seems a bit like capitalism, their main goal is to be on top and make profit. In order to make as much profit as possible, they try to look luxurious and unique to stand out. As show from the quotation:

"Whichever, he say he think I don't like him, account he American, he also remarking with me that he a barbarian and a beast. Well, me? I say I don't want him. I afraid beast. But everyone else they say yess yess ah yes he got money, and for just little while I got endure him. So, I say "Bring me that beast" and lo! One day the old nakodo he bringing him for look at meeting." (P.12)

Geisha also can choose their relatives, as these following quotation :

"She was greatly pleased with it all, though, and went about jingling her new keys and her new authority like toys, she had only one small maid to command, until she learned that among others to be excluded were her own relatives." (P.1)

There is some reason why Geisha have to do it because according to Downer, Japanese and foreign men buth find geisha to be endlessly appealing, but there are some that woreder what exactly makes them so appealing, Shuko, ageisha from the simbashi district, was actually asked what makes her and comrades so entecing Shuko replied that a geisha's requirements made them universally appealing:" firt, to be beautiful, but not to beautiful. Nex, to be able to hold one's drink, but never get drunk. Third, to devote oneself to one's art. Fourth, to be good at talking, but better at listening" Shuko confided that this was her secret to excelling in the art of conversation. In adaptation to these admirable qualities, a geisha must have pristine reputation throughout the geisha community. Unlike a prostitute or courtesan, one's reputation and prudence was vital. If a geisha was known for being promiscuous, businesses would decline drastically until she had no source of income at all (Varghese, Antony, \& Thasleena T, 2019).

Some men also will flirt to win the Geisha heart to make her fall in love with them or some also wanted to marry a Geisha. Geisha do not treat their clients as a humble servant would obey her or his master, but rather as a hostess treats her honored guests. A geisha's costumers would be referred to the entire evening as okyuakusama, meaning honored quest. In any situation a host's 
main objective is to make his or her quests fell at ease and in good humor, which is precisely what a geisha does. A geisha is also expected to use her own wit, creativity and individuality to socialize and entertain; this would be impossible if a geisha were truly meant to remain completely obedient and servile. Interaction between geisha and their quests demonstrate complete respect from both sides (Gallagher, 2012). These following quotation :

"I will give her a castle to live in said Yamadori breathlessly". The nakodo sighed. Cho Cho San refilled his pipe with an incomparable grace. "She shall have a thousand servants." She still fancies herself perhaps married to American, sighed the nakodo. (P.9)

A Geisha sometime get the bad treatment by their guest, as the following quotation :

"And though he kissed her, she went away and cried again; and Japanese girls do not often cry. " (P.3)

Geisha daily life consists of making appearances at private parties held in ochaya or tea house. They also participate regularly in public dance performance and festival. A geisha party is most usually only attended by men because of the erotic element in the atmosphere present at a gathering involving geisha. However, women may attend the dance performance or festival they participate in. A geisha is always expected to liven up the atmosphere of a dull party, even if the men she is entertaining are intolerably dull. It is geisha duty to see to it that everyone enjoys themselves in her company (Iwasaki \& Pillai, 2014). Geisha seems like an object sexual than see as an entertainer as an artist to entertain the guest from around the world. Another social condition also show that Geisha as an easy to take as a wife especially to fool by the man to be his concubine without know by the Geisha. Following quotation :

"At first, she decide to run away from him. But this, she reflected, would not probably please her relatives, since they had unanimously agreed upon the marriage for her. Besides, she preferred to remain. She had acquired a strange liking for Pinkerton and her new way of life. Finally she undertook a week remonstrance a very strong one, in fact, for a Japanese wife; but Pinkerton encouraged her pretty domestic autonomy. Her airs of authority were charming. And they grew more and more so." (P.2)

From the quotation, we can see that how Japanese people also underestimate the Geisha. How nobody speak to Geisha, seems like the Japanese have the boundaries to the Geisha.

"Account they out casting me. Everybody think me most best wicked in all Japan. Nobody speak to me. No more they all out case me except jut you; that's why I ought be sorry. But that's exact why I am not! Why use lie? It is not inside me that sorry. Me? I am most best happy female woman in Japan maybe in that whole world. What do you think? (P3)"

At 1930's American missionaries enter Japan and there are some missionaries married Japanese girl such as Pinkerton married a Geisha Cho Cho San. Japanese people also do compare between Japanese people and American. Following quotation :

"All this to explain why Madame Butterfly and her baby were reclining on the immaculate mats in attitudes of artistic abandon, instead of keeping an august states, as all other Japanese mothers and babes were at this moment doing.

\section{Japanese Social Class}

The writer finds that there are two kind of social class in the novel that reflect the social condition in Japan in 1930s which are found the Kazoku (nobleman) and heimin (proletar). The social class kind in Japanese divide by status in society, class, marriage, modern and traditional society. Madame Butterfly portrays the characters that have been include in some social high class. Some comparison how Japanese and American get their class and status by these following quotation :

"A sailor does not know the difference. In no other country are children esteemed as they are here. In America it is different. People sometimes deny them. They are left in basket at some other person's door. But he person does not receive them. They are then cared for by the municipality as wife. It is shameful to be such a child. There are great houses and many officers in each city for the 
care of these. They are an odious class by themselves, and can never rise above their first condition. (P.9)

According to Japanese social class, emperor was the top on the society class but had little power. Emperor also invited some Geisha to entertain him. Even emperor could take a Geisha as their concubine as long as she can bear a son to him. The writer also assume that only people who have a lot of money can meet Geisha. As the following quotation :

Oh, Suzuki! Someday, when the emperor go abroad, we will show him. You got say these way she changed her voice to what she fancied an impressive male basso: "Behold, Heaven-DescendedRuler-Everlasting-Great-Japan, the first of your subjects taken his eye out those version blue heaven whence you are descend! Hence the emperor look on him; then he stop an look; he kind never give enough looks. Then he make trouble a large prince! And me? He just say onto me : continue that you bring out such sons. Aha, ha, ha! What you think? (P.5)

According to Japanese class in society, a pensioned Japanese employee also get a status in society as a honorable person. As the following quotation :

He heard her laugh again as he left the courtyard; but he had confidence in the ability of Yamadori to accomplish his purpose if he could be brought into contact with her. He was one of the modern pensioned princes of Japan, a desirable matrimonial article, and preternaturally fascinating. (P.8)

\section{Conclusion}

The writer concludes based on the discussion in Chapter III that in the short story Madame Butterfly written by John Luther wrong reveal the Japanese Geisha social condition in 1930's and social class that exist in Japan. Literature and society have a relation, where literature is kind of expression of the society and it can not be separated from their environment it represent life, social reality in it. They imitate the universe, literature and society are always dependent on each other. By reading a literary work, a reader can see a social condition that describe by the author. Japan in 1930s faced the social inequality phenomenon when the gap between the upper class and the lower class was strikingly. The era of geisha began in the mid-1800s.

Through Cho Cho San the main character in Madame Butterfly was a reflection of Geisha's life condition in Japanese society. The writer conclude that Social condition of Geisha in Japan in 1930s is an entertainer because they are has been train for accompany all of the guests. Serve the drink, singing, dancing and playing music instrument were the Geisha's job while accompany the guest. The guest also did some flirting to the Geisha. In 1930s American missionary and American Navy enter Japan for some mission, there are also American people who married Japanese girl. American Navy heard about Geisha and interested to meet the Geisha. There are American people falling in love with Geisha and also married them. Geisha have a special right from the emperor, the emperor also invite them to make a show in the palace. Some of them also agree to be a mistress of the palace officials. The writer also found about the social class in Madame Butterfly, there are two social class in Japan in 1930s, which are Kazoku (nobleman) and Heimin (proletar). Kazoku is rich man such as wealthy landowner, nobleman, rich seller and Geisha include to Heimin social class because Geisha is just an artist who can earn money by entertaining their guest. According to Japanese social class, the top society class is the emperor but the emperor had little power. Imbalance social life in Japan between government and society was really contras. In 1930s, Japan face the problem such as unemployment a lot of Japanese people, increasing of the food import needed, oil, and unstable economy. Madame Butterfly portrays the characters that have been include in some social high class even she is a Geisha, because she marriage a foreigner. The social class in Japan, divide by status in society, class, marriage, modern and traditional society. According to Japanese, if a Japanese married a foreigner it can rise their social status. In addition, a Japanese pensioner's also get status in society as honorable person. 


\section{References}

Eddelbuettel, D., \& Eddelbuettel, D. (2013). Extending Rcpp. In Seamless $R$ and C++ Integration with Rcpp. https://doi.org/10.1007/978-1-4614-6868-4_6

Flaubert, G., \& Renoir, J. (2017). Madame Bovary. In Images of Idiocy: The Idiot Figure in Modern Fiction and Film. https://doi.org/10.4324/9781315135083-3

Gallagher, S. (2012). Philosophical Antecedents of Situated Cognition. In The Cambridge Handbook of Situated Cognition. https://doi.org/10.1017/cbo9780511816826.003

Groysberg, B., \& Abrahams, R. (2014). Manage your work, manage your life. Harvard Business Review.

Iwasaki, A., \& Pillai, P. S. (2014). Innate immunity to influenza virus infection. Nature Reviews Immunology. https://doi.org/10.1038/nri3665

Long, J. L. (1898). Madame Butterfly. The Century Megazine.

N., S., \& A., M. (2018). The introduction of the Cumulated Ambulatory Score (CAS) as an outcome measure in the acute rehabilitation of patients with hip fracture. European Geriatric Medicine.

Pohle, R., Tawil, A., Davydovskaya, P., \& Fleischer, M. (2011). Metal organic frameworks as promising high surface area material for work function gas sensors. Procedia Engineering. https://doi.org/10.1016/j.proeng.2011.12.027

Puspasari, N., \& Suwardi, E. (2016). THE EFFECT OF INDIVIDUAL MORALITY AND INTERNAL CONTROL ON THE PROPENSITY TO COMMIT FRAUD: EVIDENCE FROM LOCAL GOVERNMENTS. Journal of Indonesian Economy and Business. https://doi.org/10.22146/jieb.15291

Varghese, G. M., Antony, A., \& Thasleena T, T. (2019). A Study on Antenatal Corticosteroids to Reduce Neonatal Morbidity and Mortality. Indian Journal of Pharmacy Practice. https://doi.org/10.5530/ijopp.13.1.13

Wada, M. (2011). Strengthening the Kawa model: Japanese perspectives on person, occupation, and environment. Canadian Journal of Occupational Therapy. https://doi.org/10.2182/cjot.2011.78.4.4

Wellek, S. (2017). A critical evaluation of the current "p-value controversy." Biometrical Journal. https://doi.org/10.1002/bimj.201700001 